\title{
Add-on treatment with nebulized hypertonic saline in a child with plastic bronchitis after the Glenn procedure ${ }^{*, * * *}$
}

\author{
Tratamento adjuvante com nebulização de salina hipertônica em \\ uma criança com bronquite plástica após operação de Glenn
}

\author{
Grzegorz Lis, Ewa Cichocka-Jarosz, Urszula Jedynak-Wasowicz, Edyta Glowacka
}

\begin{abstract}
Plastic bronchitis (PB), although a rare cause of airway obstruction, has mortality rates up to 50\% in children after Fontan-type cardiac surgery. We present the case of an 18-month-old female patient with PB following pneumonia. At 6 months of age, the patient underwent the Glenn procedure due to functionally univentricular heart. Fiberoptic bronchoscopy revealed complete blockage of the left bronchus by mucoid casts. Pharmacotherapy consisted of glucocorticosteroids, azithromycin, and enalapril maleate. The child also received nebulized 3\% $\mathrm{NaCl}$ solution, which proved to be beneficial. In children submitted to Fontan-type procedures, physicians must be alert for $\mathrm{PB}$, which can be triggered by respiratory tract infection.
\end{abstract}

Keywords: Bronchitis; Heart defects, congenital; Saline solution, hypertonic.

\section{Resumo}

A bronquite plástica (BP), embora uma causa rara de obstrução de vias aéreas, apresenta taxas de mortalidade de até 50\% em crianças submetidas a cirurgia cardíaca do tipo Fontan. Apresentamos o caso de uma menina de 18 meses de idade com BP secundária a pneumonia. Aos 6 meses de idade, a paciente havia sido submetida à operação de Glenn devido a coração funcionalmente univentricular. A fibrobroncoscopia revelou obstrução completa do bronco esquerdo por moldes mucoides. A farmacoterapia consistiu em glicocorticosteroides, azitromicina e maleate de enalapril. Adicionalmente, a criança recebeu nebulização de solução de $\mathrm{NaCl}$ a $3 \%$, que provou ser benéfica. Em crianças submetidas a operações do tipo Fontan, devemos nos manter alerta quanto à $\mathrm{BP}$, que pode ser desencadeada por infecção do trato respiratório.

Descritores: Bronquite; Cardiopatias congênitas; Solução salina hipertônica.

\section{Introduction}

Plastic bronchitis (PB), despite being a rare cause of airway obstruction, has a high mortality rate (up to 50\%). Therefore, physicians should maintain a high level of clinical suspicion of $\mathrm{PB}$, which is most often seen in children with congenital heart disease (CHD) after Fontan-type procedures. However, PB can also affect adults. ${ }^{(1)}$ In addition, PB can occur due to pulmonary lymphatic abnormalities, respiratory tract allergies, infectious diseases, or acute chest syndrome in sickle cell disease. ${ }^{(2)}$ Anecdotally, PB has been reported in cystic fibrosis patients and postoperatively in heart transplant patients. ${ }^{(3,4)}$

In the pathophysiology of PB due to CHD, Fontan circulation predisposes to dysfunction of membranes, leading to leakage of proteinaceous material into the airways. This can cause significant obstruction by the formation of branching gelatinous casts in the tracheobronchial tree. The casts might be either spontaneously expectorated or require bronchoscopy for their removal as a lifesaving procedure. Death due to airway obstruction from a cast is not uncommon. ${ }^{(2)}$ Clinical symptoms and $\mathrm{X}$-ray findings are nonspecific and might mimic foreign body aspiration or severe asthma exacerbation. There are two known types of casts, differing histologically and in their composition ${ }^{(5)}$ : type 1-inflammatory, associated with underlying inflammatory disease of the lung-consisting of fibrin with eosinophilic, neutrophilic, and lymphocytic infiltration; and type 2-acellular, associated with pulmonary hypertension and heart

*Study carried out in the Department of Pediatrics, Chair of Pediatrics, Jagiellonian University Medical College, Cracow, Poland. Correspondence to: Grzegorz Lis. 265 Wielicka Str. 30-663, Cracow, Poland. Tel. 481265820 11. E-mail: milis@cyf-kr.edu.pl Financial support: None.

Submitted: 11 December 2012. Accepted, after review: 1 February 2013.

${ }^{* *}$ A versão completa em português deste artigo está disponível em www.jornaldepneumologia.com.br 
insufficiency due to CHD-consisting of mucin, with no infiltration. Because PB is rare, there are no specific recommendations for treatment, and therapeutic options are mainly based on individual experience.

\section{Case report}

We present the case of an 18-month-old female patient with PB following pneumonia. At 2 months of age, the patient was hospitalized due to pneumonia. At 6 months of age, she underwent a palliative bidirectional Glenn procedure (Fontan-type) due to CHD (doubleinlet and double-outlet ventricle with common atrioventricular canal). The perioperative period was uneventful. Echocardiography at 12 and 18 months of age showed proper heart function (ejection fraction, 67\%). At 18 months of age, she was again hospitalized due to pneumonia that remained unresolved after three courses of antibiotics in the home setting. Infiltration and atelectasis of the left upper lobe had been clinically suspected (because of dullness and diminished breath sounds over that region) and was confirmed by a chest X-ray. Blood pressure was normal. However, $\mathrm{SpO}_{2}$ was approximately $50 \%$ (having previously been at 70-80\%). In addition, hypogammaglobulinemia was detected. In the differential diagnosis, we excluded atopy, cystic fibrosis, immunodeficiency disorders, viral infections (with cytomegalovirus, Epstein-Barr virus, and pneumotropic viruses), and fungal infections (Aspergillus sp. and Candida sp.). Within a few days, her coughs were more productive and there was expectoration of small mucoid casts. Despite antibiotic treatment, gamma-globulin replacement therapy, oxygen therapy, and intensive chest physiotherapy, as well as the use of nebulized bronchodilators and mucolytics, there was no clinical improvement. On post-admission day 17 , fiberoptic bronchoscopy (FB) revealed complete obliteration of the left bronchus. Application of suction allowed to remove bronchial casts, followed by bronchial lavage of that region (Figure 1). Cultures of the bronchial lavage fluid were negative for fungi and bacteria. Microscopic analysis of the material collected revealed type-1 bronchial casts. After the bronchoscopy, the inflammation of the left lobes was resolved. Treatment with azithromycin, systemic and inhaled steroids, ${ }^{6}{ }^{6}$ and enalapril maleate was initiated, as was the use of nebulized $3 \% \mathrm{NaCl}$ solution plus a bronchodilator. One week after treatment initiation, a control FB revealed only small fragments of casts, which were removed easily and completely. On post-admission day 33, the patient was discharged.

\section{Discussion}

In children, PB is uncommon. In one study, Madsen et al. reviewed 56 well-documented cases of PB after cardiac surgery conducted prior to 2005. ${ }^{(2)}$ Thereafter, two groups of authors described the cases of 32 adults and 22 children, respectively, in China. ${ }^{(7,8)}$ In addition, two studies on PB were carried out in Poland..$^{(9,10)}$ To our knowledge, this is the first reported case of $\mathrm{PB}$ in a child with CHD in Poland. Our patient was 18 months old at admission, with moderately severe symptoms of PB, which differs from the two fatal cases of PB after a Glenn procedure cited by Madsen et al. ${ }^{(2)}$ Patients with PB due to CHD tend to be younger and have a poorer prognosis than do those with PB due to other comorbidities. In our patient, PB occurred 9 months after the Glenn procedure and was triggered by a respiratory infection, which is in agreement with other reports. ${ }^{(2)}$ The present case highlights the fact that PB should be considered in cyanotic children presenting with asymmetry on chest examination, a history of cardiac surgery, and moderately severe infectious respiratory symptoms. Spontaneously expectorated bronchial casts, as were those observed in the case reported here, usually substantiate the diagnosis. Hypothetically, the incidence of PB in children is likely to be underdiagnosed because of the difficulty in productive expectoration at this age. Bronchoscopy could be a diagnostic and treatment option in PB. ${ }^{(2)}$ In our patient, we managed to remove the bronchial casts during the FB procedure. However, massive casts might require rigid bronchoscopy. Histological examination is important, although not always clinically relevant. In cases of overlapping infection after cardiac surgery, inflammatory casts might be present, as was exemplified in our patient. This is also in line with other reports, because respiratory tract infection in children might be coincidental or causative. ${ }^{(10)}$ In the present case, the results of microscopic examination of the bronchial cast justified the modification of the treatment to the well-known options of azithromycin and systemic corticosteroids. Our patient benefited from the use of nebulized hypertonic saline (3\% 


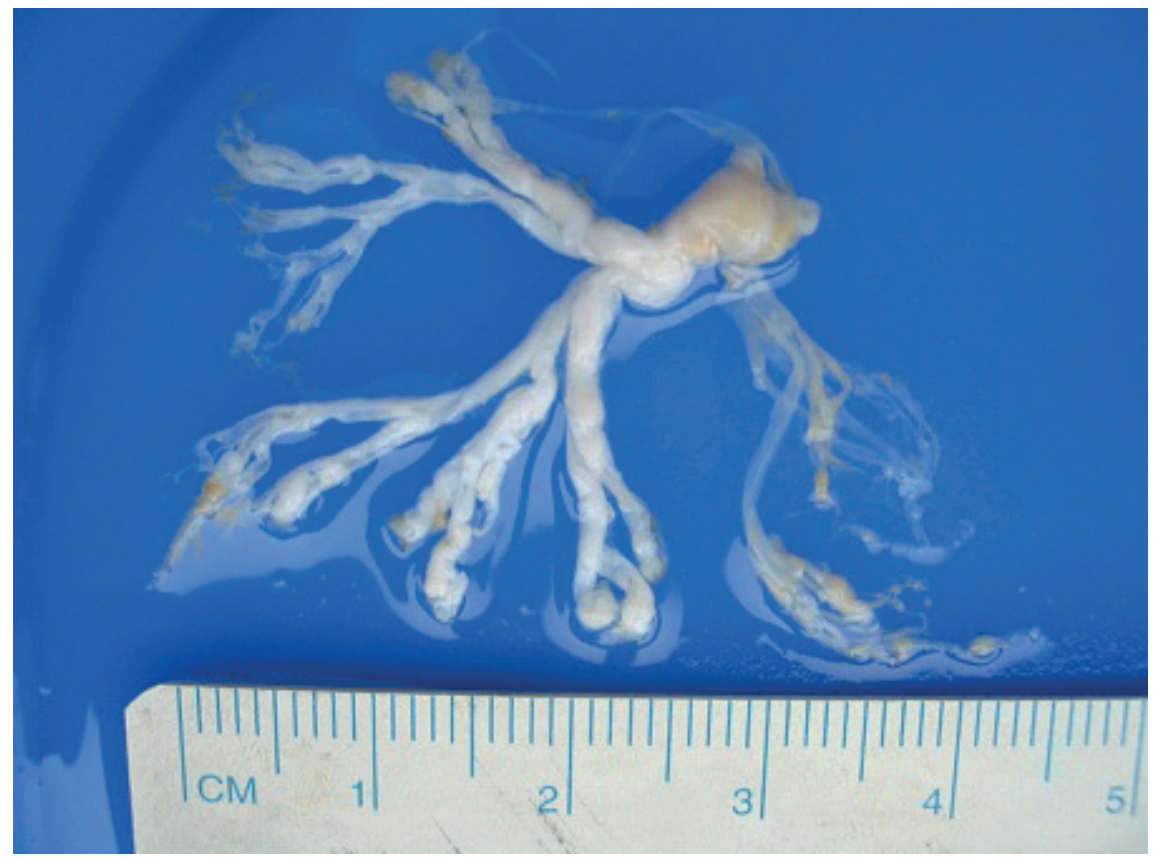

Figure 1 - Branching cast from the left bronchus.

$\mathrm{NaCl}$ ), which, to our knowledge, was an empirical treatment reported for the first time in a patient with PB. Improvement in expectoration, lack of cast recurrence, and a positive outcome were observed. Other attempts, including the use of aerosolized urokinase, tissue plasminogen activator, and recombinant human DNase, as well as extracorporeal membrane oxygenation, have been reported anecdotally. ${ }^{(8)}$ We did not introduce sildenafil citrate, which has been reported to be used successfully in combination with epoprostenol..$^{(11)}$

In summary, children with a functionally univentricular heart after a Fontan-type procedure require constant vigilance on the part of physicians for $\mathrm{PB}$, which can be triggered by respiratory tract infection. In some cases, FB might be suitable for the removal of casts. Because of the vast spectrum of underlying comorbidities, therapy should be individualized, and the use of nebulized hypertonic saline might be beneficial.

\section{References}

1. Ugurlucan M, Basaran M, Alpagut U, Tireli E. Bidirectional inferior vena cava-pulmonary artery shunt: can it be alternative for older patients presenting single ventricle heart disease in the third world countries? Arch Med Sci. 2008;4:1-6.

2. Madsen P, Shah SA, Rubin BK. Plastic bronchitis: new insight and classification scheme. Paediatric Respir
Rev. 2005;6(4):292-300. http://dx.doi.org/10.1016/j. prrv.2005.09.001

3. ElMallah MK, Prabhakaran S, Chesrown SE. Plastic bronchitis: resolution after heart transplantation. Pediatr Pulmonol. 2011;46(8):824-5. http://dx.doi.org/10.1002/ ppul. 21432

4. Mateos-Corral D, Cutz E, Solomon M, Ratjen F. Plastic bronchitis as an unusual cause of mucus plugging in cystic fibrosis. Pediatr Pulmonol. 2009;44(9):939-40. http://dx.doi.org/10.1002/ppul.21063

5. Seear M, Hui H, Magee F, Bohn D, Cutz E. Bronchial casts in children: a proposed classification based on nine cases and a review of literature. Am J Respir Crit Care Med. 1997;155(1):364-70. http://dx.doi.org/10.1164/ ajrccm.155.1.9001337

6. Do P, Randhawa 1, Chin T, Parsapour K, Nussbaum E. Successful management of plastic bronchitis in a child post Fontan: case report and literature review. lung. 2012;190(4):463-8. http://dx.doi.org/10.1007/ s00408-012-9384-x

7. Dabo L, Qiyi Z, Jianwen Z, Zhenyun H, Lifeng Z. Perioperative management of plastic bronchitis in children. Int J Pediatr Otorhinolaryng. 2010;74(1):15-21. http:// dx.doi.org/10.1016/j.ijporl.2009.09.028

8. Wang G, Wang Y, Luo F, Wang L, Jiang L, Wang L, et al. Effective use of corticosteroids in treatment of plastic bronchitis with hemoptysis in Chinese adults. Acta Pharmacol Sin. 2006;27(9):1206-12. http://dx.doi. org/10.1111/j.1745-7254.2006.00418.x

9. Sledziewska J, Załeska J, Wiatr E, Płodziszewska M, Załeska M, Pirozynski M, et al. Plastic bronchitis and mucoid impaction--uncommon disease syndromes with expectoration mucus plugs [Article in Polish]. Pneumonol Alergol Pol. 2001;69(1-2):50-61.

10. Krenke K, Krenke R, Krauze A, Lange J, Kulus M. Plastic bronchitis: an unusual cause of atelectasis. Respiration. 2010;80(2):146-7. http://dx.doi.org/10.1159/000243711 
11. Haseyama K, Satomi G, Yasukochi S, Matsui H, Harada Y, Uchita S. Pulmonary vasodilation therapy with sildenafil citrate in a patient with plastic bronchitis after the
Fontan procedure for hypoplastic left heart syndrome. J Thoracic Cardiovasc Surg. 2006;132(5):1232-3. http:// dx.doi.org/10.1016/j.jtcvs.2006.05.067

\section{About the authors}

\section{Grzegorz Lis}

Professor. Department of Pediatrics, Chair of Pediatrics, Jagiellonian University Medical College, Cracow, Poland.

\section{Ewa Cichocka-Jarosz}

Associated Professor. Department of Pediatrics, Chair of Pediatrics, Jagiellonian University Medical College, Cracow, Poland.

Urszula Jedynak-Wasowicz

Associated Professor. Department of Pediatrics, Chair of Pediatrics, Jagiellonian University Medical College, Cracow, Poland

\section{Edyta Glowacka}

Assistant. Department of Pediatrics, Chair of Pediatrics, Jagiellonian University Medical College, Cracow, Poland. 